\title{
\begin{tabular}{l|l|l} 
Volume 9 & Number 5 & May 2018
\end{tabular}
}

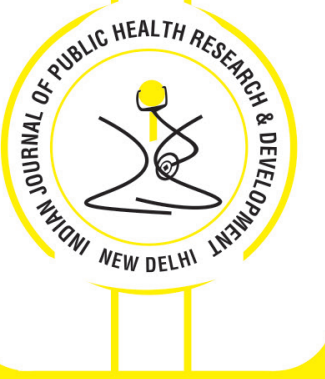

\section{Indian Journal of}

\section{Public Health Research \& Development}

An International Journal

\section{SCOPUS IJPHRD CITATION SCORE}

Indian Journal of Public Health Research and Development Scopus coverage years: from 2010 to 2017 Publisher: R.K. Sharma, Institute of Medico-Legal Publications ISSN:0976-0245E-ISSN: 0976-5506 Subject area: Medicine:

Public Health, Environmental and Occupational Health

CiteScore 2015-0.02

SJR 2015-0.105

SNIP 2015- 0.034

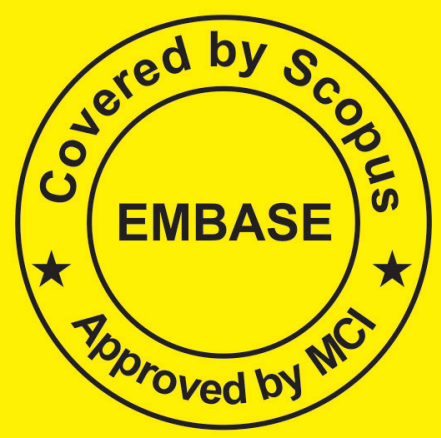

Website: 


\title{
An Analysis of Risk Management in the Process of Inspection Activities in the Port Health Office (PHO) Class I Surabaya
}

\author{
Dewi Novita Hardianti ${ }^{1}$, Tri Martiana ${ }^{2}$, Abdul Rohim Tualeka ${ }^{2}$ \\ ${ }^{I}$ Student in Magister of Occupational Health and Safety, ${ }^{2}$ Lecturer in Departement of Occupational Health and \\ Safety, Faculty of Public Health, Airlangga University Campus C Mulyorejo, Surabaya-Indonesia
}

\begin{abstract}
The high number of accidents is merely caused by the dysfunction of the OSH management. One of the efforts to decrease the number of accidents is by applying HSMS through the implementation of risk management. Based on the observation and interview events almost wretched is often the case, one of them slipped due to slippery floor of the boat. In July 2015, there was an accident that killed the officer of Port Health Office due to collisions of speedboat in South Kalimantan. Several incidents above show that the process of inspection of the vessel is very risky to work accidents. Therefore, risk management is required.

This study was a descriptive study that was conducted in March-June 2017. The aim was to analyze the safety risk management on inspector job of ships in Port Health Office Class 1 Surabaya. The standard used is AS/ NZS 4360: 2004. This research was a semi quantitative research design with cross sectional and observational research. The object of this study was the hazard and the risk of OSH contained in the ship inspection activities. Technique of data collection was done by using observations, interviews and FGD.

The results of the risk assessment shows $41 \%$ low risk and 59\% medium risk and high hazard risk level is not found. Because there are several control which already exist and have been carried out, such as the availability of PPE is complete, the SOP of work, the measurement of the quality of the working environment and implementation of training. Meanwhile, a system for recording and reporting occupational accidents have not been implemented. Therefore, need to make an organization dealing with OSH and create a system for recording and reporting occupational accidents in which all incidents of workplace accidents can be recognized and controlled quickly and precisely.
\end{abstract}

Keywords: Risk Management, Work Accident of Port Health Office (PHO), Ships Inspector.

\section{INTRODUCTION}

Port Health Office (PHO) is a unit of organization in charge of implementing the prevention of entrance and exit of the disease, a potential disease outbreaks, epidemiological surveillance, quarantine, control of environmental health impacts. Health services,

\section{Corresponding author}

Prof. Dr. Tri Martiana, dr., M.S.

Lecturer in Departement of Occupational Health and Safety Faculty of Public Health, Airlangga University Campus C Mulyorejo 60115, Surabaya-Indonesia medication monitoring medical devices and cosmetics food addictive substances (OMKABA) as well as safeguards against re-emerging diseases, bioterrorism, elements of biology, chemistry and security radiation of working area ports and land border state ${ }^{1}$, Many potential hazards and risks that can be generated OSH. Therefore need a way to prevent or control to prevent and reduce occupational accidents in accordance with the Indonesian Government Regulation No. 50 year 2012 on the implementation of Health and Safety Management System (HSMS) as a way to prevent workplace accidents ${ }^{2}$, Beside that, the Minister of Manpower At No.05/ Men/ 1996 requires the existence of risk management in the workplace ${ }^{3}$. 
Data Social Security Agency (BPJS) Employment mentions the figure of occupational accidents in Indonesia is still high. Until the end of 2015, there were 105182 work accidents cases happen. The number of workplace accidents in Indonesia each year increased up to $5 \%{ }^{4}$, The main cause of accidents is that there is still low awareness of the importance of risk management in the industry since HSMS is consider as a cost or expense, rather than as an investment to prevent accidents.

The implementation of risk management on Health and Safety Management System (HSMS) aims to help the management to prevent losses to be happen through risk management accurately. In the risk management, risk assessment is very influential in determining the effect or exposure of potential hazard, since through a risk assessment, occupational accident can be prevented or eliminated. Risk management is the core management of higher system of OSH which requires the existence of risk management ${ }^{5}$, An organization that implement any risk management methods which therefore having the methods to identify, evaluate and prioritize risks and control the risk by short-term and long term approach ${ }^{6}$.

Results of interviews to ship inspectors found that the incidence of almost wretched (Near Miss) is often the case, one of them slipped due to slippery floor of the boat and sandwiched between two of the ship when crossing. In July 2015, there was an accident that killed the officer of Port Health office due to collisions speedboat and small boat in South Kalimantan Kotabaru. The accident occurred when the officer is heading to the ship to conduct inspection of ships. However, about 100 meters from the harbor there was small boat that want to advance in the direction of a speedboat, because it was blocked by a wooden barge (place to sell oil at sea), speedboat ended up colliding with a wooden raft. Information obtained from field officers, officers were killed due to hit the edge of the speedboat. Before the strike, the victim was hit by a speedboat carrying raft, after collision, speed boat struck a barge mooring oil selling wood not far from Port Office Kotabaru?

Accidents above are one hazard that can occur when performing inspection of ships. Often overlooked risk management implementation and assume that all hazards have been addressed and there were no serious accidents remarks. The risk management process should be implemented fully in the workplace, and repeated periodically to ensure that all hazards have been identified. The risks have been assessed in adequate measures to control the risks in the workplace. Risk management program is a management responsibility, while the worker role is one of support and assistance in the implementation and application of risk management in the workplace.

Some of the previously mentioned exposure indicated that the implementation of risk management in the workplace indirectly prevent and reduce accidents, prevent and control the incidence of occupational diseases. The end result of the implementation of risk management are increasing productivity, improving morale and relationship relations or relations company for the better.

This study aims toanayze the safety riskanagement (risk identification, risk analysis, risk evaluation, risk control) on work inspection of ships in Port Health Office Class 1 Surabaya.

\section{MATERIAL AND METHOD}

This research is descriptive observational approach cross sectional. The research was conducted in March June 2017 at Port Health Office (PHO) class I Suabaya. This study was included in the semi-quantitative research, The object of this study was the hazard and risk of OSH contained in the process of ship inspection activities. Technique of data collection was done by using observations, interviews and FGD (focus group discussions). Interviews and FGDs conducted the inspection of ships employee. The number of employees who are interviewed and Include in the FGD process were 13 people (Permanent Employee and temporary employees). The standards used in assessing the risk in the risk management was by using the New Zealand Standard (AS / NZS 4360: 2004).

Natural hazard identification and risk OSH, the method used is a Task Risk Assessment (TRA). In addition the method is also used in performing risk analysis $\mathrm{OSH}$ at a stage of the work process to determine the level of risk by calculating the consequences of $\mathrm{OSH}$, the likelihood and frequency of exposure of each risk. The data collected in the process of this research is primary data and secondary data. The primary data obtained through observation, interviews and focus group discussions on workers in order to get an overview of hazard and risk identification and control OSH (Exsiting control) has been done by the Port Health 
Office in preventing the occurrence of an event. While secondary data obtained from documents on the Port Health Office Class 1 of Tanjung Perak Office Surabaya.

\section{FINDING}

The process of ship inspector jobs in The Port Health Office Class I Surabaya is conducted from a trip to the dock (1), enters the dock area (2), boarding (3), conduct inspection of the vessel (ship sanitation inspection, health inspection and (4) Down the ship (5), and a journey to the port health office $(6)^{8}$. Activities of risk identification is the first step in risk management that aims to determine the safety problem exists in the process of work. All activities are performed in each process of work performed has a wide variety of potential safety hazards. Results of those hazards identification then analyzed to determine the amount of risk and the level of risk, and whether those risks are acceptable or not. To find and determine the level of risk through a risk assessment by determining the value of likelihood, the value of the exposure, the value of the consequences ${ }^{9}$, The risk assessment in terms of likelihood seen from the behavior of officers in work and the work environment, in terms of exposure views of how long exposure to either chemical, biological and physical while doing inspection of ships as well as the travel time officer to get to the ship and to ports as well as in terms of the consequences seen from the consequences that may result from an incident/ accident.

All risks are identified and assessed by using the category level of risk of high, moderate, and low. The process of identifying up to risk assessment using Task Risk Assessment (TRA) ${ }^{10}$, The results of the risk assessment is used as a basis for determining risk control alternatives.

Table 1. Results of risk identification and risk assessment on work inspection of ships in Port Heath Office Class I Surabaya

\begin{tabular}{|c|c|c|c|c|c|c|}
\hline \multirow[b]{3}{*}{ Potential hazard } & \multicolumn{6}{|c|}{ Ship Inspection activities } \\
\hline & 1 & 2 & 3 & 4 & 5 & 6 \\
\hline & $\begin{array}{l}\text { The journey to } \\
\text { the dock }\end{array}$ & $\begin{array}{l}\text { Entering the } \\
\text { pier Territory }\end{array}$ & Boarding ship & Ship inspection & $\begin{array}{l}\text { descend } \\
\text { Ship }\end{array}$ & $\begin{array}{l}\text { Journey Into } \\
\text { Office }\end{array}$ \\
\hline Nudge & M & M & & & M & M \\
\hline Crash & $\mathrm{L}$ & $\mathrm{L}$ & & & $\mathrm{L}$ & $\mathrm{L}$ \\
\hline The Fall Containers & & M & & & M & \\
\hline fall overboard & & & M & & M & \\
\hline Stair stumble & & & $\mathrm{L}$ & & $\mathrm{L}$ & \\
\hline slip & & & M & $\mathrm{L}$ & M & \\
\hline $\begin{array}{l}\text { sandwiched between } \\
2 \text { Ships }\end{array}$ & & & M & & & \\
\hline Crushed Food Shelves & & & & $\mathrm{L}$ & & \\
\hline Scratched Sharps & & & & $\mathrm{L}$ & & \\
\hline Toxicity of Chemicals & & & & M & & \\
\hline Virus/ disease & & & & M & & \\
\hline
\end{tabular}

Information :

\begin{tabular}{|l|l|}
\hline M & Medium Risk \\
\hline L & Low Risk \\
\hline
\end{tabular}

Based on the results of the identification and assessment of risks of inspector job of ship in The Port Health Office Class I Surabaya showed that the average stage of his work in the category of low/ acceptable. Prevention also needs to be done even though the ship inspection activity was found into the category of low risk/ acceptable. The level of low and medium risk was found not to be high risk and could endanger workers. Control to prevent accidents from happening is to always wear PPE complete, perform safety talk before working 
its purpose is to remind employees/ workers will be potential hazards in the workplace in order to establish safe behavior at work and help employees/ workers to identify and control hazards, in addition to the CTF parties also need to conduct surveillance, monitoring and evaluation in order to determine all the input data or information obtained from these observations can form the basis for making decisions further action is necessary. Such action is necessary if the observations indicate the presence or condition of things that do not fit.

The process of supervision, monitoring and evaluation should be accompanied by a system of recording and reporting of workplace accidents to be used as guidelines in conducting the investigation and reporting of occupational accidents and can determine the factors causes of accidents and to prevent similar accidents from happening again.

\section{CONCLUSION}

Hazard identification process carried out on the ship inspector job in Port Health Office Class I Surabaya produced 22 hazards.

Levels of risk found are a medium-risk and low-risk levels, whereas there is no danger or high level found.

Control needs to be done in order to prevent all high risk with administrative controls (Safety Talk, supervision, monitoring and evaluation, as well as the recording and reporting of workplace accidents) and the use of PPE.

\section{Conflict of Interest: None}

Source of Funding: Department of Occupational Health and Safety, Airlangga University, Surabaya, Indonesia

Ethical Clearance: The study was approved by the ethical committee of Airlangga University
All subjects were fully informed about the procedures and objectives of this study and each subject prior to the study signed an informed consent form.

\section{REFERENCES}

1. Regulation of the Minister of Health of the Republic of Indonesia No. 2348 / Menkes / Per / XI / 2011 concerning Amendment to Regulation of the Minister of Health No. 356 / Menkes / Per / IV / 2008 on the Organization and Work of the Port Health Office.

2. Government Regulation 50 of 2012 on the Safety Management System and Occupational Health.

3. RI Department of Labor (1996), the Minister of Manpower and Transmigration No.05 / MEN / 1996 on Management System Occupational Health and Safety.

4. http://www.bpjsketenagakerjaan.go.id/berita/5769/ Jumlah-kecelakaan-kerja-di-Indonesiamasih-tinggi. html (Cited February 24, 2017).

5. Rudi Suardi. (2005). Management System Occupational Health and Safety. Jakarta: PPM.

6. Sitorus AT. (2010). Hazard Identification and Risk Assessment Occupational Safety and Health in 2009. Semarang State University.

7. http://banjarmasin.tribunnews.com/2015/07/30/ speedboat-vs-balapan-pegawai-kesehatan-tewas (Cited January 26, 2017)

8. Regulation of the Minister of Health of the Republic of Indonesia Number 40 Year 2015 About Ship Sanitation Certificates.

9. Standards Australia / New Zaeland. (2004). 4360. Risk Management Standards Association Of Australia, Strathfield.

10. https://maddenmaritime.files.wordpress. com/2013/02/step-change-task-risk-assessmentguide.pdf(Cited dated February 30, 2017). 